\title{
Pengaruh Panjang Serat Pinang Terhadap Sifat Mekanik dan Uji Biodegradasi Material Komposit Matriks Epoksi dengan Penambahan Pati Talas
}

\author{
Sindy Dwi Putri Dynanty*, Alimin Mahyudin** \\ Laboratorium Fisika Material, Jurusan Fisika \\ Fakultas Matematika dan Ilmu Pengetahuan Alam Universitas Andalas \\ Kampus Unand Limau Manis, Padang, 25163 Indonesia \\ *sindydwi@gmail.com, **aliminmahyudin23@gmail.com
}

\begin{abstract}
ABSTRAK
Telah dilakukan penelitian mengenai pengaruh panjang serat pinang terhadap sifat mekanik dan fisik material komposit matriks epoksi dengan penambahan pati talas. Variasi panjang serat $3 \mathrm{~mm}, 6 \mathrm{~mm}, 9$ $\mathrm{mm}, 12 \mathrm{~mm}$, dan $15 \mathrm{~mm}$. Fraksi volume serat yaitu 3\%. Hasil pengujian didapatkan nilai kuat tarik tertinggi pada panjang serat $3 \mathrm{~mm}$ yaitu 11,02 MPa. Pada pengujian modulus elastisitas diperoleh nilai tertinggi pada panjang serat $12 \mathrm{~mm}$ yaitu 132,52 $\mathrm{MPa}$. Nilai regangan dan kuat impak tertinggi pada panjang serat $9 \mathrm{~mm}$ yaitu $10 \%$ dan $0,0052 \mathrm{~J} / \mathrm{mm}^{2}$. Nilai biodegradasi rata-rata yaitu sebesar $0,098 \%$.

Kata kunci: serat pinang, epoksi, pati talas, kuat tarik, kuat impak, biodegradasi.
\end{abstract}

\section{ABSTRACT}

The research the effect of fiber length of areca nut fiber to the mechanical properties and biodegradation test of epoxy matrix composite material with the addition of taro starch has been conducted. Variations of the fiber length are $3 \mathrm{~mm}, 6 \mathrm{~mm}, 9 \mathrm{~mm}, 12 \mathrm{~mm}$, and $15 \mathrm{~mm}$. Volume fraction of the fiber is $3 \%$. Results show that the highest tensile strength value obtained at fiber length of $3 \mathrm{~mm}$ that is $11.02 \mathrm{MPa}$. The highest modulus of elasticity obtained at fiber length of $12 \mathrm{~mm}$ that is $132.52 \mathrm{MPa}$. Highest strain and impact strength are at fiber length of $9 \mathrm{~mm}$ that is $10 \%$ and $0.0052 \mathrm{~J} / \mathrm{mm}^{2}$. The average value of the biodegradation is $0.098 \%$.

Keywords: areca nut fiber, epoxy, taro starch, tensile strength, impact strength, biodegradation.

\section{PENDAHULUAN}

Pemanfaatan dan penggunaan komposit telah berkembang pesat dan meluas di tanah air ini. Komposit banyak dimanfaatkan dalam peralatan rumah tangga dan sektor industri baik industri kecil maupun industri besar. Hal ini disebabkan karena komposit memiliki beberapa keunggulan tersendiri seperti bahan komposit lebih kuat, tahan terhadap korosi, lebih ekonomis, dan lain-lain. Komposit merupakan suatu material yang terbentuk dari kombinasi dua atau lebih material sehingga dihasilkan material komposit yang mempunyai sifat mekanik dan karekteristik yang berbeda dari material pembentuknya.

Komposit terdiri dari matriks yang berfungsi untuk perekat atau pengikat dan pelindung filler (pengisi) dari kerusakan eksternal dan filler berfungsi sebagai penguat. Berdasarkan jenis penguatnya, secara umum dikenal tiga kelompok komposit yaitu komposit berpenguat partikel, komposit berpenguat serat, dan komposit berpenguat laminat (Matthews dan Rawlings, 1994).

Material komposit yang berpenguat serat terutama serat alam merupakan material alternatif yang sangat menguntungkan. Serat alam dapat diperoleh dari berbagai variasi tumbuhan. Serat ini telah digunakan dalam sektor industri seperti automotif, tekstil, produksi kertas dan dalam komposit material. Terkait dengan penggunaan serat alam sebagai penguat dalam komposit, mereka mempunyai keuntungan antara lain kekuatan spesifik dan modulusnya yang tinggi, densitas rendah, harga rendah, melimpah di banyak negara, emisi polusi yang lebih rendah dan dapat di daur ulang (Joshi dkk., 2004).

Salah satu tanaman yang memiliki potensi untuk dimanfaatkan sebagai serat penguat material komposit adalah serat pinang. Serat pinang memiliki sifat mekanik yang baik. Binoj dkk. (2016) telah meneliti sifat mekanik serat pinang dengan kekuatan tarik sebesar 147-322 $\mathrm{MPa}$, modulus elastisitas 1,124-3,155 GPa, dan regangan 10,23-13,15\%.

Matriks sebagai pengikat yang digunakan yaitu polimer blend antara polimer sintetis dan alam. Polimer sintetis yang digunakan yaitu resin epoksi. Resin epoksi memiliki sifat mekanik yang baik dan tahan terhadap suhu tinggi, akan tetapi apabila resin ini dipanaskan 
untuk yang kesekian kalinya, resin epoksi tidak dapat meleleh yang menyebabkannya tidak dapat didaur ulang dan dapat merusak lingkungan. Oleh karena itu ditambahkan polimer alam berupa pati untuk mengurangi masalah lingkungan.

Kamagi (2017) telah menguji kekuatan mekanik dari serat buah pinang menggunakan matriks epoksi variasi serat dengan fraksi volume 3\%, 5\%, 7\%, dan 9\% dengan panjang serat $3,5 \mathrm{~cm}$ yang disusun acak. Hasil pengujian tarik menunjukan komposit serat buah pinang, kekuatan tarik dan regangan rata-rata terbesar terdapat pada komposit dengan persentasi volume serat 3\% dengan nilai $40,705 \mathrm{MPa}$ dan $2,48 \%$, sedangkan yang terkecil pada persentasi volume $7 \%$ dengan nilai $35,713 \mathrm{MPa}$ dan 2,0\%. Nilai modulus elastisitas rata-rata terbesar terdapat pada komposit berpenguat serat pinang $7 \%$ dengan nilai 18,265 MPa dan terkecil pada komposit berpenguat serat pinang $9 \%$ dengan nilai $14,548 \mathrm{MPa}$. Komposit berpenguat serat pinang yang disusun acak memiliki pengaruh untuk meningkatkan nilai modulus elastisitasnya.

Hidayat dkk. (2015) telah melakukan penelitian tentang pengaruh penambahan pati talas terhadap sifat mekanik dan degradabilitas plastik campuran polipropilena dan gula jagung. Pada penelitian ini penambahan pati talas yang divariasikan sebanyak $0 \mathrm{~g}, 9 \mathrm{~g}, 12 \mathrm{~g}, 15 \mathrm{~g}$, dan $18 \mathrm{~g}$. Nilai kuat lentur dan tarik tertinggi diperoleh dari sampel dengan penambahan pati talas 9 g, yaitu 37,44 N/mm2 dan 5,19 N/mm2. Sampel yang paling cepat terdegradasi adalah sampel dengan penambahan pati talas sebanyak $18 \mathrm{~g}$, dengan laju degradasi rata-rata 0,68\% per hari. Komposisi bahan terbaik belum didapatkan karena nilai kekuatan uji yang diperoleh berada pada komposisi yang berbeda-beda.

Pada penelitian ini akan digunakan serat pinang sebagai filler (pengisi), sedangkan matriks yang digunakan adalah resin epoksi dengan penambahan pati talas. Penelitian ini menggunakan metode two dimensional reinforcement pada tata letak dan arah serat. Parameter uji yang digunakan adalah sifat mekanik yaitu kuat tarik dan kuat impak, serta pengujian biodegradasi.

\section{METODE}

Penelitian dilaksanakan di Laboratorium Fisika Material Jurusan Fisika, FMIPA Unand untuk pengujian biodegradasi. Pengujian kuat tarik dan kuat impak dilakukan di Laboratorium Mekanik Politeknik Negri Padang. Teknik penelitian yang digunakan adalah metode blend dan hand lay up dengan beberapa tahapan, diantaranya:

\subsection{Persiapan dan Pembuatan Spesimen}

Serat pinang dijemur sampai kering di bawah sinar matahari selama 2 hari. Pengolahan serat pinang dilakukan secara tradisional meliputi pemisahan dan perendaman serat. Serat direndam dengan larutan alkali $\mathrm{NaOH} 5 \%$ selama 2 jam. Setelah direndam serat pinang dibilas dengan air untuk menghilangkan kandungan $\mathrm{NaOH}$ yang tersisa lalu serat sabut pinang dikeringkan dengan oven bersuhu $\pm 40^{\circ} \mathrm{C}$ selama 2 jam untuk meghilangkan kadar air yang tersisa. Selanjutnya serat sabut pinang dipotong sepanjang $3 \mathrm{~mm}, 6 \mathrm{~mm}, 9 \mathrm{~mm}, 12 \mathrm{~mm}$ dan 15 $\mathrm{mm}$.

Pati yang diperoleh dari umbi talas sebanyak $9 \mathrm{~g}$ ditambah aquades sebanyak $30 \mathrm{ml}$. Larutan tersebut diaduk menggunakan magnetic stirrer pada kecepatan $200 \mathrm{rpm}$ dan suhu $105^{\circ} \mathrm{C}$ selama 20 menit. Selanjutnya gula jagung sebanyak $10 \mathrm{~g}$ terhadap ditambahkan dan diaduk selama 10 menit setelah itu didinginkan. Resin epoxy dan epoxy hardener disiapkan dengan perbandingan campuran resin 1:1 lalu dituangkan dan dicampurkan ke dalam gelas ukur kemudian diaduk sampai rata. Selanjutnya dicampurkan dengan pati yang telah dibuat. Serat pinang sebanyak 3\% dari volume cetakan kemudian disusun di atas matriks dengan arah two dimensional reinforcement. Cetakan ditutup kembali dengan matriks hingga terisi penuh. Komposit didiamkan hingga kering selama 24 jam dan dikeluarkan dari cetakan. 


\subsection{Pengujian dan Pengambilan Data}

\subsubsection{Kuat Tarik}

Uji kuat tarik merupakan salah satu uji stress-strain mekanik yang bertujuan untuk mengetahui kekuatan bahan terhadap gaya tarik. Pengukuran kuat tarik dirumuskan seperti persamaan:

$$
\sigma=\frac{F}{A}
$$

dengan $\sigma$ adalah kuat tarik $\left(\mathrm{kg} / \mathrm{cm}^{2}\right), F$ adalah gaya tarik tegak lurus terhadap permukaan $(\mathrm{kg})$, dan $A$ adalah luas bidang spesimen yang ditarik $\left(\mathrm{cm}^{2}\right)$.

Regangan atau strain adalah perubahan pada ukuran benda karena gaya dalam kesetimbangan dibandingkan dengan ukuran semula. Regangan dapat diukur dengan menggunakan persamaan:

$$
\varepsilon=\frac{\Delta l}{l}
$$

dengan $\varepsilon$ adalah regangan, $\Delta l$ adalah perubahan panjang spesimen $(\mathrm{cm})$, dan $l$ adalah panjang spesimen $(\mathrm{cm})$.

Modulus elastisitas adalah perbandingan antara tegangan dan regangan. Modulus elastisitas didapatkan menggunakan persamaan:

$$
E=\frac{\sigma}{\varepsilon}
$$

dengan $E$ adalah modulus elastisitas $\left(\mathrm{kg} / \mathrm{cm}^{2}\right)$.

\subsubsection{Kuat Impak}

Uji impak adalah jenis pengujian yang dilakukan untuk mengetahui seberapa besar kekuatan material tersebut. Nilai harga impak dapat dihitung menggunakan persamaan:

$$
H I=\frac{E}{A}
$$

dengan $H I$ adalah harga impak $\left(\mathrm{J} / \mathrm{mm}^{2}\right), E$ adalah energi serap impak $(\mathrm{J})$, dan $A$ adalah luas penampang $\left(\mathrm{mm}^{2}\right)$.

\subsubsection{Kuat Impak}

Metode kuantitatif yang paling sederhana untuk menguji terjadinya biodegradasi suatu polimer adalah dengan menentukan kehilangan massa dan degradabilitas material polimer. Persentase kehilangan massa dapat ditentukan dengan persamaan:

$$
\% \text { mass } a=\frac{m i-m f}{m i} \times 100 \%
$$

dengan $m i$ adalah massa spesimen sebelum proses biodegradasi (g) dan $m f$ adalah massa spesimen sesudah proses biodegradasi (g).

Degradabilitas suatu materi dapat ditentukan dengan melihat hasil persen massa yang diperoleh dalam selang waktu tertentu. Secara matematis degradabilitas dapat dilihat pada persamaan:

$$
\text { Degradasi }=\frac{\% \text { massa }}{\text { waktu }}
$$




\section{HASIL DAN DISKUSI}

\subsection{Kuat Tarik}

Pada penelitian ini, uji kuat tarik dilakukan untuk mengetahui seberapa besar pengaruh fraksi massa dan orientasi serat terhadap kekuatan tarik, regangan, dan modulus elastisitas yang dimiliki oleh masing-masing spesimen uji. Berdasarkan hasil pengujian dan perhitungan didapat data seperti pada Gambar 1.

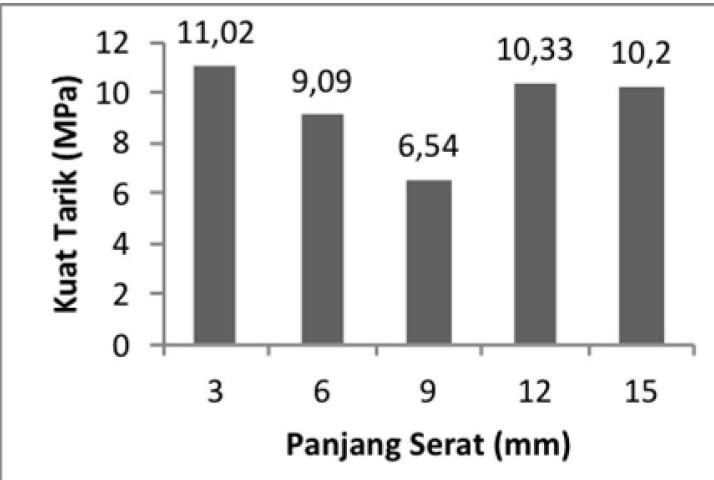

Gambar 1 Pengaruh panjang serat terhadap kuat tarik resin epoksi dicampur pati talas

Berdasarkan Gambar 1 nilai kuat tarik yang didapatkan tidak linear atau mengalami fluktasi terhadap panjang serat pada komposit, hal ini disebabkan adanya pengaruh dari perletakan serat dan ikatan antara matriks dan serat. Serat pendek dengan orientasi yang merata akan menghasilkan kekuatan yang lebih tinggi jika dibandingkan serat panjang. Komposit berserat pendek dapat diproduksi dengan cacat permukaan yang rendah sehingga kekuatannya dapat mencapai kekuatan teoritisnya (Schwartz, 1984).

Nilai kuat tarik tertinggi resin epoksi dicampur pati talas didapat pada variasi panjang serat $3 \mathrm{~mm}$ yaitu 11,02 MPa dan kuat tarik terendah pada panjang serat $9 \mathrm{~mm}$ yaitu sebesar 6,54 $\mathrm{MPa}$, hal ini bisa disebabkan adanya ikatan antaramuka (interface) matriks dan serat kurang baik. Pada panjang serat $3 \mathrm{~mm}$ gaya adhesinya lebih tinggi yang menandakan ikatan antara matriks-serat lebih baik dan menurun seiring pertambahan panjang serat pada $6 \mathrm{~mm}$ dan $9 \mathrm{~mm}$. pada panjang serat $12 \mathrm{~mm}$ kekuatan tarik mulai naik dan menurun pada panjang $15 \mathrm{~mm}$, hal ini disebabkan serat panjang dapat mengalirkan beban maupun tegangan dari titik tegangan ke arah serat yang lain. Pada struktur continous fiber yang ideal, serat akan bebas tegangan atau mempunyai tegangan yang sama. Selama fabrikasi, beberapa serat akan menerima tegangan yang tinggi dan yang lain mungkin tidak terkena tegangan sehingga keadaan di atas tidak dapat tercapai (Schwartz, 1984).

Nilai regangan dihasilkan dari perbandingan pertambahan panjang spesimen terhadap panjang mula-mula. Berdasarkan hasil dari pengujian dan perhitungan didapat data untuk nilai regangan seperti pada Gambar 2.

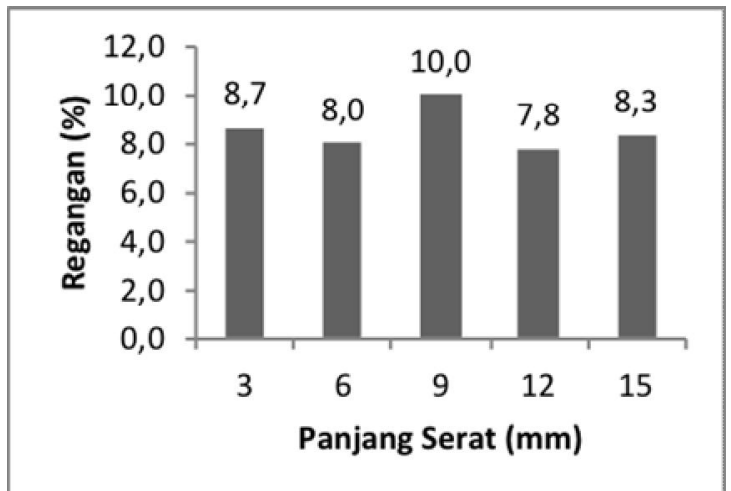

Gambar 2 Pengaruh panjang serat terhadap regangan resin epoksi dicampur pati talas 
Berdasarkan Gambar 2 dapat dilihat bahwa nilai regangan tertinggi diperoleh dari panjang serat $9 \mathrm{~mm}$ yaitu sebesar $10 \%$ dan yang terendah pada serat $12 \mathrm{~mm}$ yaitu sebesar 7,8 $\%$. Pada panjang serat $9 \mathrm{~mm}$ adanya gaya adhesi yang kecil yang menyebabkan ikatan antara molekulnya tidak kuat yang menyebabkan spesimen uji mudah memanjang dan terlepas dari ikatannya. Hal ini menunjukkan bahwa nilai regangan juga di pengaruhi oleh ikatan antara matriks dan serat.

Dari nilai kuat tarik dan regangan yang didapatkan, maka diperoleh nilai modulus elastisitas. Modulus elastisitas yang didapatkan dari pengaruh panjang serat pinang dapat dilihat pada Gambar 3.

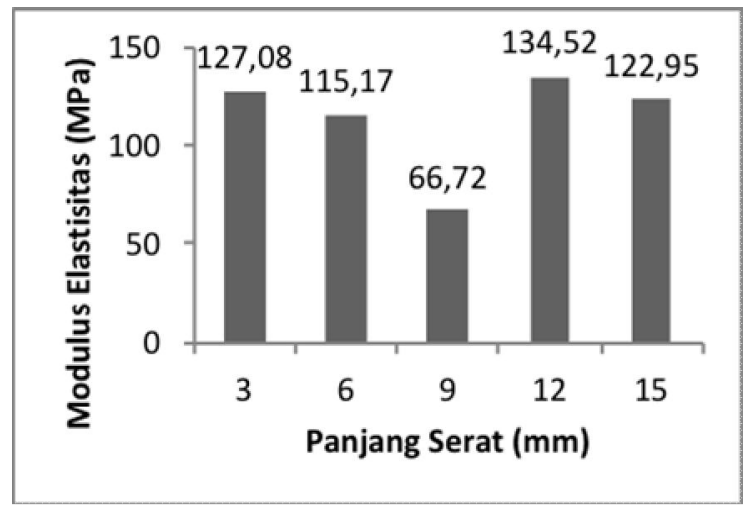

Gambar 3 Pengaruh panjang serat terhadap modulus elastisitas resin epoksi dicampur pati talas

Gambar 3 melihatkan bahwa nilai modulus elastisitas tertinggi pada panjang serat 12 $\mathrm{mm}$ yaitu sebesar 132,52 MPa dan yang terendah pada panjang serat $9 \mathrm{~mm}$ yaitu sebesar 66,72 MPa. Hal ini disebabkan dari hubungan perbandingan antara kuat tarik terhadap regangan yang mana nilai modulus elastisitas berbanding lurus terhadap nilai kuat tarik dan berbanding terbalik terhadap regangan.

Kerusakan yang banyak terjadi pada komposit disebabkan karena tidak melekatnya serat terhadap bahan pelekatnya yaitu resin yang biasa disebut debonding. Debonding dapat terjadi pada komposit karena beberapa hal seperti serat yang menumpuk, kandungan lapisan serat yang tidak menyatu pada matriks, dan kondisi serat yang kurang bersih saat melakukan pembuatan komposit. Terjadinya debonding maka dapat berdampak berkurangnya kekuatan komposit dan kurangnya fungsi sebagai bahan penguat pada bahan pengikat.

\subsection{Kuat Impak}

Uji kuat impak dilakukan untuk mengetahui besarnya energi yang diserap untuk mematahkan spesimen. Dari hasil pengujian didapatkan nilai harga impak seperti pada Gambar 4.

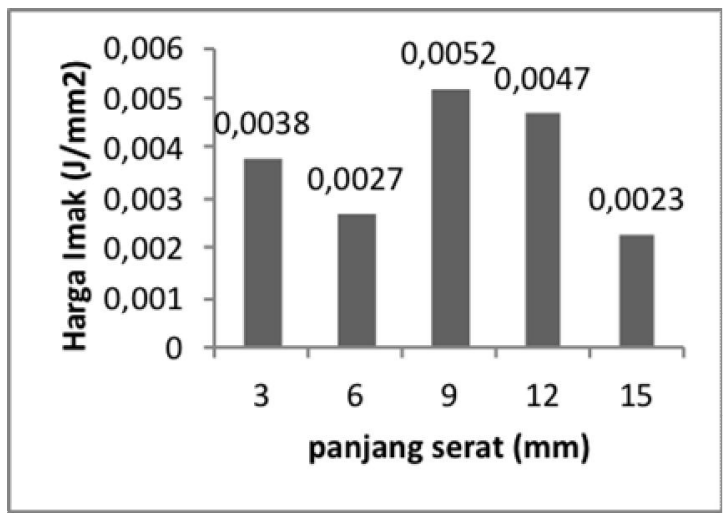

Gambar 4 Pengaruh panjang serat terhadap harga impak resin epoksi dicampur pati talas 
Dari Gambar 4 di atas dapat dilihat bahwa panjang serat $9 \mathrm{~mm}$ mempunyai harga impak yang tertinggi yaitu sebesar $0,0052 \mathrm{~J} / \mathrm{mm}^{2}$ dan panjang serat $15 \mathrm{~mm}$ memiliki nilai harga impak terendah yaitu sebesar $0,0023 \mathrm{~J} / \mathrm{mm}^{2}$. Perbedaan harga impak dari variasi panjang serat juga dapat disebabkan oleh beberapa faktor diantaranya gaya adhesi yang rendah sehingga kemampuan komposit untuk menyerap energi yang diberikan menjadi lebih kecil. Adanya penambahan pati pada komposit ini menyebabkan nilai harga impak lebih baik karena pati yang dicampurkan pada epoksi mampu menyerap energi lebih baik.

\subsection{Biodegradasi}

Pengujian biodegradasi bertujuan untuk menentukan laju perubahan massa spesimen setelah penguburan. Proses degradasi dapat diketahui dengan cara melihat perubahan massa spesimen sebelum dan sesudah penguburan di dalam tanah dalam rentang waktu tertentu. Pada Gambar 5 dapat dilihat nilai degradasi spesimen setelah penguburan selama 40 hari.

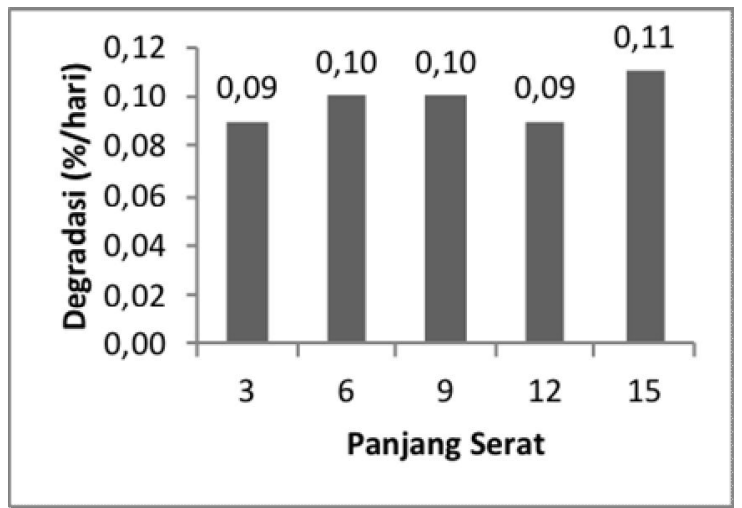

Gambar 5 Pengaruh panjang serat terhadap degradasi resin epoksi dicampur pati talas

Panjang serat pada uji degradasi tidak berpengaruh dikarenakan komposisi setiap spesimen uji sama yang menyebabkan tidak adanya perubahan yang signifikan. Pati talas dicampurkan pada resin epoksi guna untuk meningkatkan proses degradasi, sehingga spesimen akan mudah terurai dikarenakan pati talas disukai oleh mikroba. Perbedaan massa awal tiap-tiap spesimen juga mempengaruhi hasil perhitungan degradasi yang tidak linear. Faktor lain yang sangat berpengaruh terhadap degradasi adalah kelembaban dan banyaknya mikroba pengurai dalam tanah (Firdaus dan Anwar, 2004). Adanya jarak antara sampel selama penguburan mengakibatkan kelembaban dan jumlah mikroba dalam tanah berbeda-beda. Nilai rata-rata dari biodegradasi didapatkan yaitu sebesar $0,098 \%$.

\section{KESIMPULAN}

Pada penelitian belum didapatkan panjang serat yang optimum pada pengujian, hal ini dikarenakan nilai kekuatan optimum pada tiap-tiap pengujian terdapat pada panjang serat yang berbeda. Nilai kuat tarik optimum didapatkan pada panjang serat $3 \mathrm{~mm}$ yaitu 11,02 MPa. Nilai modulus elastisitas optimum pada panjang serat $12 \mathrm{~mm}$ yaitu 134,52 $\mathrm{MPa}$. Nilai regangan dan kuat impak optimum didapatkan pada panjang serat $9 \mathrm{~mm}$ yaitu $10 \%$ dan $0,0052 \mathrm{~J} / \mathrm{mm}^{2}$. Nilai rata-rata dari biodegradasi didapatkan yaitu sebesar $0,098 \%$.

\section{DAFTAR PUSTAKA}

Binoj, J.S., Raj, R.E., Sreenivasan, V.S., dan Thusnavis, G.R., "Morphological Physical, Mechanical, Chemical and Thermal Characterization of Sustainable Indian Areca Fruit Husk Fibers as Potential Alternate for Hazardous Syntethic Fibers", Journal of Bionic Engineering, 13, 156-165 (2016).

Firdaus, F., dan Anwar, C., "Potensi Limbah Padat-Cair Industri Tepung Tapioka Sebagai Bahan Baku Film Plastik Biodegradabel", Logika, 1, 38-44 (2016).

Hidayat, R., Mulyadi, S., dan Hamdani., S., "Pengaruh Penambahan Pati Talas Terhadap sifat Mekanik dan Sifat Biodegradabel Plastik Campuran Polipropilena dan Gula Jagung", 
Joshi, S.V., Drzal, L.T., Mohanty, A.K., dan Arora, S., "Are Natural Fiber Composites Environmentally Superior to Glass Fiber reinforced Composites?", Composites: Part A, 35, 371-376 (2004).

Kamagi, J.R.F.D., "Sifat Komposit Berpenguat Serat Buah Pinang dengan Variasi Fraksi Volume 3\%, 5\%, 7\%, dan 9\%", Skripsi S1, Universitas Sanata Dharma, 2017.

Matthews, F.L. dan Rawlings, R.D., Composite Material: Engineering And Science, (Woodhead Publishing Series in Composite Science and Engineering) (Chapman \& Hall, London, 1994).

Schwartz, M., "Composite Material Handbook”, (Mc Graw Hill, New York, 1984). 